\title{
Invitro Evaluation of Bio Control Agents against Blast of Foxtail Millet Caused by Pyricularia setariae
}

\author{
B. Mallikarjuna*, M. S. Nagaraj and K. B. Palanna \\ Department of Plant Pathology, College of Agriculture, \\ UAS, GKVK, Bengaluru-560065, India \\ *Corresponding author
}

\section{A B S T R A C T}

Keywords

bio control agents, mycelial growth, per cent inhibition, dual culture method, volatile method, Pyricularia setariae

Article Info

Accepted:

25 February 2020

Available Online:

10 March 2020
Foxtail millet is a highly nutritious crop affected by several diseases, of which leaf blast is an important disease, hindering productivity. The present study was conducted to evaluate the in vitro efficacy of different bio control agents. Fourteen bio control agents which includes five bacterial, five bacterial endophytes and four fungal are evaluated under in vitro condition by using dual culture and volatile method. Among these $\mathrm{P}_{42}$ strain of Bacillus velezensis showed cent per cent inhibition of mycelial growth followed by bacterial endophyte Enterobacter cloacae $(56.80 \%)$ in dual culture method whereas Th14 strain of T. harzianum shows highest mycelial growth inhibition $(77.6 \%)$ followed by $T h 55$ strain $(76.81 \%)$ in volatile method.

\section{Introduction}

Foxtail millet [Setaria italica (L.) Beauv.] is an ancient cultivated crop and most economically important species of the genus Setaria belongs to family poaceae and Native to China (Vavilov, 1926). This crop has high importance as it is a rich source of nutrients and grown for both food and fodder purpose. It is also known by several other names such as German millet, Italian millet, Chinese millet and Hungarian millet (Baker, 2003). It ranks $2^{\text {nd }}$ in the total world production of millets and continues to have an important place in the world agriculture providing around six million tons of food to millions of world population, mainly on marginal or poor soils in Southern Europe and in temperate, subtropical and tropical Asia (Marathee, 1993). It is widely grown throughout Africa, China, India, Russia, and the United States.

In India foxtail millet is grown on about 1 million ha, mainly in northern Karnataka, parts of costal Andhra Pradesh, Uttarakhand, Tamil Nadu, and some parts of the 
northeastern states. The grain is used as both food and fodder. It is a good source of carbohydrate, protein and essential amino acids and it is a very good datary component for diabetic and heart patients because it contains magnesium (Marathee, 1993). The grains are good source of protein, minerals (calcium, iron, potassium, magnesium and zinc) and vitamins (Rai, 2002). It is widely used as an energy source for pregnant, lactating women, sick people and children (Sema and Sarita, 2002). It has got medicinal value as it is used as curative for rheumatism and measles (Wright and Finch, 1962) and also it has been suggested that foxtail millet is used as a food component to cardiovascular diseases and type 2 diabetes (Choi et al., 2005).

Although foxtail millet has high nutritional importance and grown for both food and fodder purpose, the crop is affected by several biotic and abiotic constraints. Among the biotic constraints fungal diseases like leaf blast, brownspot, rust, downy mildew and bacterial diseases like bacterial streak are limiting the production of the crop. Among these diseases, blast caused by the fungus Pyricularia setariae Sacc. (teleomorph: Magnaporthe setariae) is the most destructive disease and affects both forage and grain production of foxtail millet. Symptoms of the disease appear as circular spots with straw colored centers on leaf blades.

The spots are small and scattered, 2 to $5 \mathrm{~mm}$ in diameter and surrounded by a dark brown margin. When the disease appears in severe form during humid weather conditions, especially with a dense plant stand, the leaves wither and dry. Plants are infected at all growth stages of crop growth (Gaikwad, and D' Souza, 1987); lower leaves are the most severely affected. Recognizing the importance of foxtail millet and the constraint caused by the leaf blast disease, the present study was planned to evaluate different bio control agents under in vitro condition to generate primary data on effective bio control agents against $P$. setariae and identified potential bio control agents will be used in designing Integrated Disease Management strategies for management of blast there by production and productivity of the crop will be enhanced.

\section{Materials and Methods}

In vitro evaluation was carried out with bio agents (Table.1) through dual culture and volatile method.

\section{Dual culture technique}

In the dual culture technique, sterilized PDA media was cooled and about $20 \mathrm{~mL}$ of media was poured into sterile Petri plates. Fungal antagonists were evaluated by inoculating the $P$. setariae at one peripheral end of Petri plate and the antagonist on the opposite peripheral end of the same plate by leaving 3 to $4 \mathrm{~cm}$ gap. Similarly, for bacterial antagonists fungal disc was placed at one peripheral end of Petri plate and bacterial antagonists were streaked at other end of same plate. Each treatment was replicated three times. After 10 days of incubation period the radial growth of pathogen was measured. Per cent inhibition over control was worked out according to the equation of Vincent (1947).

\section{Volatile metabolites}

The efficacy of all fourteen bio control agents were evaluated against $P$. setariae on Potato dextrose agar medium to test inhibitory effect of volatile compounds under in vitro conditions.

For this study $20 \mathrm{~mL}$ of PDA was poured into each Petri dish. A $5 \mathrm{~mm}$ diameter agar disc from the two days old pure culture of each of 
fungal bio control agent culture was placed at centre of each agar plate. Similarly, bacterial bio control agents were streaked on previously poured Petri dish containing PDA. Afterwards the disk of same size was taken from $P$. setariae culture and placed in another agar plate. The lids were removed and test fungus culture plate was immediately placed over each of bio control agents plates held together with adhesive tapes.

The space prevented any physical contact between pathogen and bio control agent, so that the volatile compounds were formed and confined to the interior atmosphere of the two plates. For the control plate, only $P$. setariae culture placed on PDA plate. Each treatment was replicated three times. After 10 days of incubation period the radial growth of pathogen was measured. Per cent inhibition over control was worked out according to the equation of Vincent (1947).

$$
I=\frac{(\mathrm{C}-\mathrm{T})}{\mathrm{C} \ldots \ldots \ldots} \times 100
$$

Where, $\mathrm{I}=$ Per cent inhibition of mycelium $\mathrm{C}=$ Growth of mycelium in control $\mathrm{T}=$ Growth of mycelium in treatment

\section{Statistical analysis}

The data generated by different experiments were analyzed using the WASP software developed by ICAR- Central Coastal Agricultural Research Institute, Goa and the inferences were made with a probability of one per cent.

\section{Results and Discussion}

The fungal antagonists such Trichoderma harzianum, T. viride and their strains were collected from Mycology lab Department of Plant Pathology, GKVK. These bio control agents were evaluated against $P$. setariae under in vitro condition for their efficacy by using dual culture technique as described in material and methods. Among these Th14 strain of $T$. harzianum showed highest mycelial growth inhibition (57.70 \%) followed by $T h \mathrm{~B} 5$ strain of $T$. harzianum $(42.82 \%)$ and least mycelial growth inhibition was observed in Th55 strain. $T$. harzianum.

Ten different bacterial bio control agents were tested against $P$. setariae by using dual culture method. Among these bacterial bio control agents $\mathrm{P}_{42}$ strain of Bacillus velezensis showed cent per cent inhibition of mycelial growth followed by bacterial endophyte Enterobacter cloacae $(56.80 \%)$ and least inhibition of mycelial growth observed in Bacillus megatorium which accounted 2.07 per cent (Table 2, plate 1, fig 1).

Volatile Organic Compounds (VOC) produced by microorganisms played an important role during their evolution while interaction with other organisms. Such interaction results in functional response by the organism which involved in coincidental disadvantage to other microorganisms. Hence the effect of volatile compounds produced by all fourteen bio control agents was tested against $P$. setariae by using volatile method as described in material and methods (section 3.5.1B). Among these bio control agents highest mycelial growth inhibition recorded in Th14 strain of $T$. harzianum (77.6 \%) followed by $T h 55$ strain $(76.81 \%)$ and least inhibition of mycelia was observed in Bacillus megatorium (38.45 \%) (Table 2, plate 2, fig 2).

Utilization of bio control agents for the management of diseases is the important strategy in IDM practices and currently has important role in the organic farming system. So, in the present study, different Trichoderma spp and bacterial bio control 
agents were evaluated against $P$. setariae under in vitro conditions. The Trichoderma spp. were found more effective against the fungus and it is reported that inhibition of the mycelial growth was due to coiling of hyphae of the pathogen by Trichoderma (Ali and Nadarajah 2014).

It may also due to the cell wall degrading enzyme produced by Trichoderma spp. which has high endochitinase action that results in breakdown of the cell wall (Chitin) as reported by Kalaivani et al., (2014). Fuji et al., (1978) and Vinale et al., (2008) he also reported that secondary metabolites produced by Trichoderma spp. such as antibiotics (6pentyl-alpha-pyrone (6pp), isocyanide derivatives), acids (heptelidic and koningic acid) and peptaibols that are resulted in the inhibition of radial growth of numerous plant pathogenic fungi. Similarly, Somashekhar Konda (2015) reported that Trichoderma spp. were effective against $P$. setariae. Several other workers (Watanabe, 1985; Gouramanis, 1997; Hajano et al., 2012 and Arumugam et al., 2013) also described that Trichoderma spp. were very effective against $P$. oryzae.

Table.1 Bio agents used for in vitro evaluation against the $P$. setariae

\begin{tabular}{|c|c|c|c|}
\hline $\begin{array}{c}\text { SI } \\
\text { No. }\end{array}$ & Bio agents & $\begin{array}{c}\text { Strain/ } \\
\text { Isolate }\end{array}$ & Source \\
\hline 1 & Bacillus subtilis & - & Bacteriology lab, UAS, GKVK, \\
Bengaluru
\end{tabular}


Table.2 In vitro efficacy of bio agents against $P$. setariae

\begin{tabular}{|c|c|c|c|}
\hline \multirow{2}{*}{$\begin{array}{l}\text { Sl } \\
\text { No. }\end{array}$} & \multirow[t]{2}{*}{ Bio control agents } & \multicolumn{2}{|c|}{ Per cent. inhibition of mycelial growth } \\
\hline & & Dual culture method & Volatile method \\
\hline 1 & Bacillus subtilis & $\begin{array}{c}16.26 \\
(23.77)\end{array}$ & $\begin{array}{c}56.74 \\
(48.87)\end{array}$ \\
\hline 2 & B. megatarium & $\begin{array}{c}2.07 \\
(8.26)\end{array}$ & $\begin{array}{c}38.45 \\
(38.32)\end{array}$ \\
\hline 3 & B. velezensis $\left(\mathrm{A}_{6}\right)$ & $\begin{array}{c}48.31 \\
(44.03)\end{array}$ & $\begin{array}{c}62.47 \\
(52.22)\end{array}$ \\
\hline 4 & Pseudomonas fluorescens & $\begin{array}{c}22.72 \\
(28.46)\end{array}$ & $\begin{array}{c}61.88 \\
(51.87)\end{array}$ \\
\hline 5 & B. velezensis $\left(\mathrm{P}_{42}\right)$ & $\begin{array}{l}100.00 \\
(90.00)\end{array}$ & $\begin{array}{c}61.13 \\
(51.43)\end{array}$ \\
\hline 6 & Bacillus spp. (GPUR-12) & $\begin{array}{c}55.56 \\
(48.19)\end{array}$ & $\begin{array}{c}58.93 \\
(50.14)\end{array}$ \\
\hline 7 & B. cereus (GPUR-10) & $\begin{array}{c}45.22 \\
(42.25)\end{array}$ & $\begin{array}{c}53.14 \\
(46.80)\end{array}$ \\
\hline 8 & B. mojarensis (UMR-9) & $\begin{array}{c}50.94 \\
(45.54)\end{array}$ & $\begin{array}{c}54.59 \\
(47.63)\end{array}$ \\
\hline 9 & Enterobacter cloacae (GPUL-19) & $\begin{array}{c}56.80 \\
(48.90)\end{array}$ & $\begin{array}{c}50.88 \\
(45.50)\end{array}$ \\
\hline 10 & Pennibacillus polymyxa (GPUS-13) & $\begin{array}{c}38.46 \\
(38.32)\end{array}$ & $\begin{array}{c}61.31 \\
(51.54)\end{array}$ \\
\hline 11 & Trichoderma viride (Tv1) & $\begin{array}{c}38.63 \\
(38.43)\end{array}$ & $\begin{array}{c}64.65 \\
(53.52)\end{array}$ \\
\hline 12 & T. harzianum(Th14) & $\begin{array}{c}57.70 \\
(49.43)\end{array}$ & $\begin{array}{c}77.6 \\
(61.75)\end{array}$ \\
\hline 13 & T. harzianum(ThB5) & $\begin{array}{c}42.82 \\
(40.60)\end{array}$ & $\begin{array}{c}66.65 \\
(54.73)\end{array}$ \\
\hline 14 & T. harzianum(Th55) & $\begin{array}{c}38.08 \\
(38.10)\end{array}$ & $\begin{array}{c}76.81 \\
(61.21)\end{array}$ \\
\hline & Control & 0.0 & 0.0 \\
\hline & SEm \pm & 2.01 & 0.21 \\
\hline & $\mathrm{CD}(0.01)$ & 6.02 & 0.69 \\
\hline
\end{tabular}

Among the different bacterial bio control agents, maximum mycelial growth inhibition $(100 \%)$ was showed by $\mathrm{P}_{42}$ stain of Bacillus velezensis followed by bacterial endophyte Enterobacter cloacae (56.80 \%). Similarly, Karthikeyan and Gnanamanickam (2008) also found that the growth of $P$. setariae was 3.0 and $2.5 \mathrm{~cm}$ due to inhibition of Pseudomonas fluorescens and Pf-52 Bacillus polymyxa VLB-17 respectively. In this study, bacterial endophytes of Bacillus species were also found effective against $P$. setariae this was due to the activity of antibiotic like substance. Bacillus produces different antibiotic substances that are effective against many fungi such as Zwittermycin-A (He et al., 1994), Kanamycin, lipopeptida and fengycin (Stabb et al., 1994). Mubariket et al., (2010) reported chitinase activity of Bacillus cereus. Harman (2000) and Leelasuphakul et al., (2006) also found 60 per. cent inhibition of $P$. grisea by $B$. subtilis strain NSRS 89-24i. 


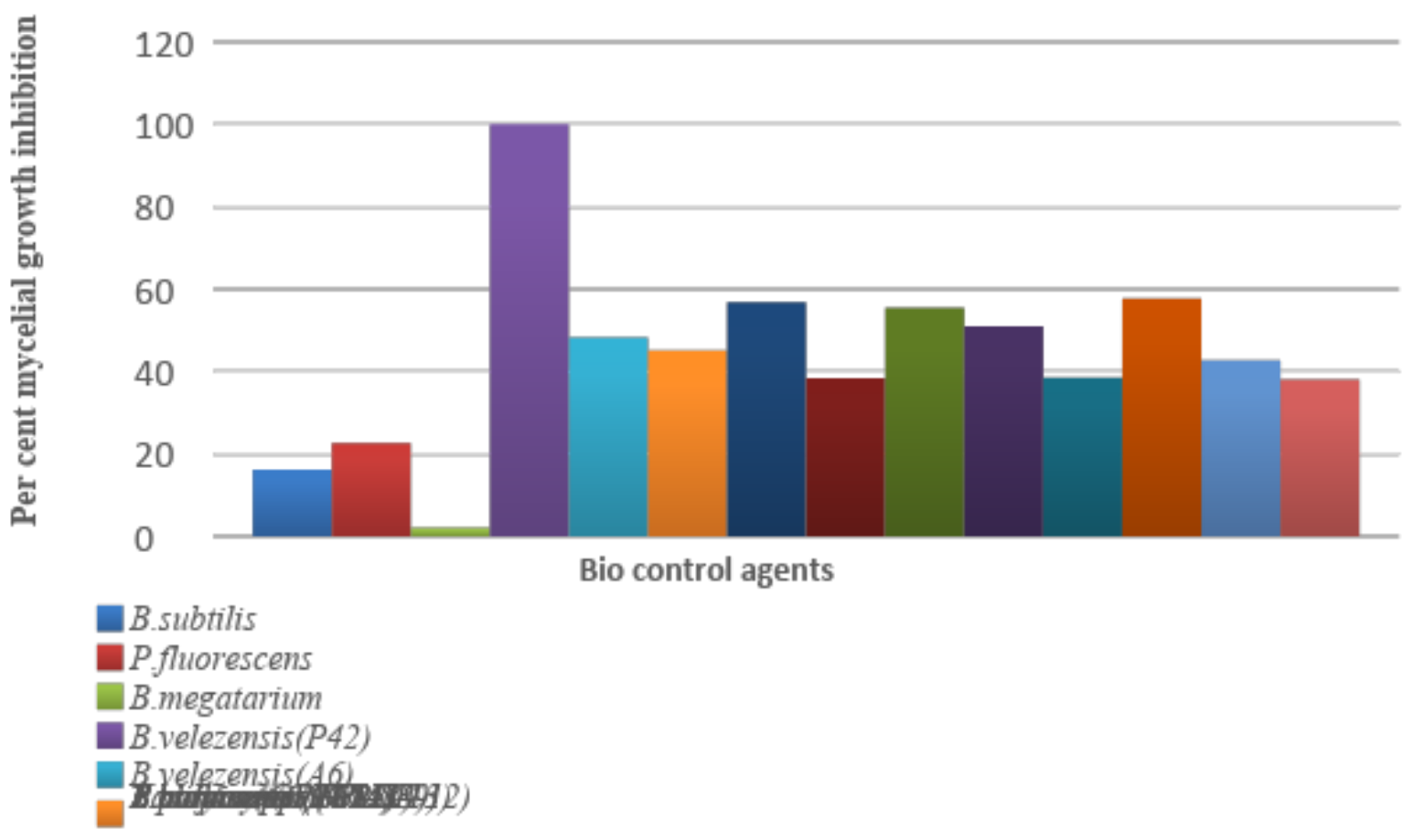

Fig.1 Effect of bio agents on the mycelial growth inhibition of P.setariae (Dual culture technique)

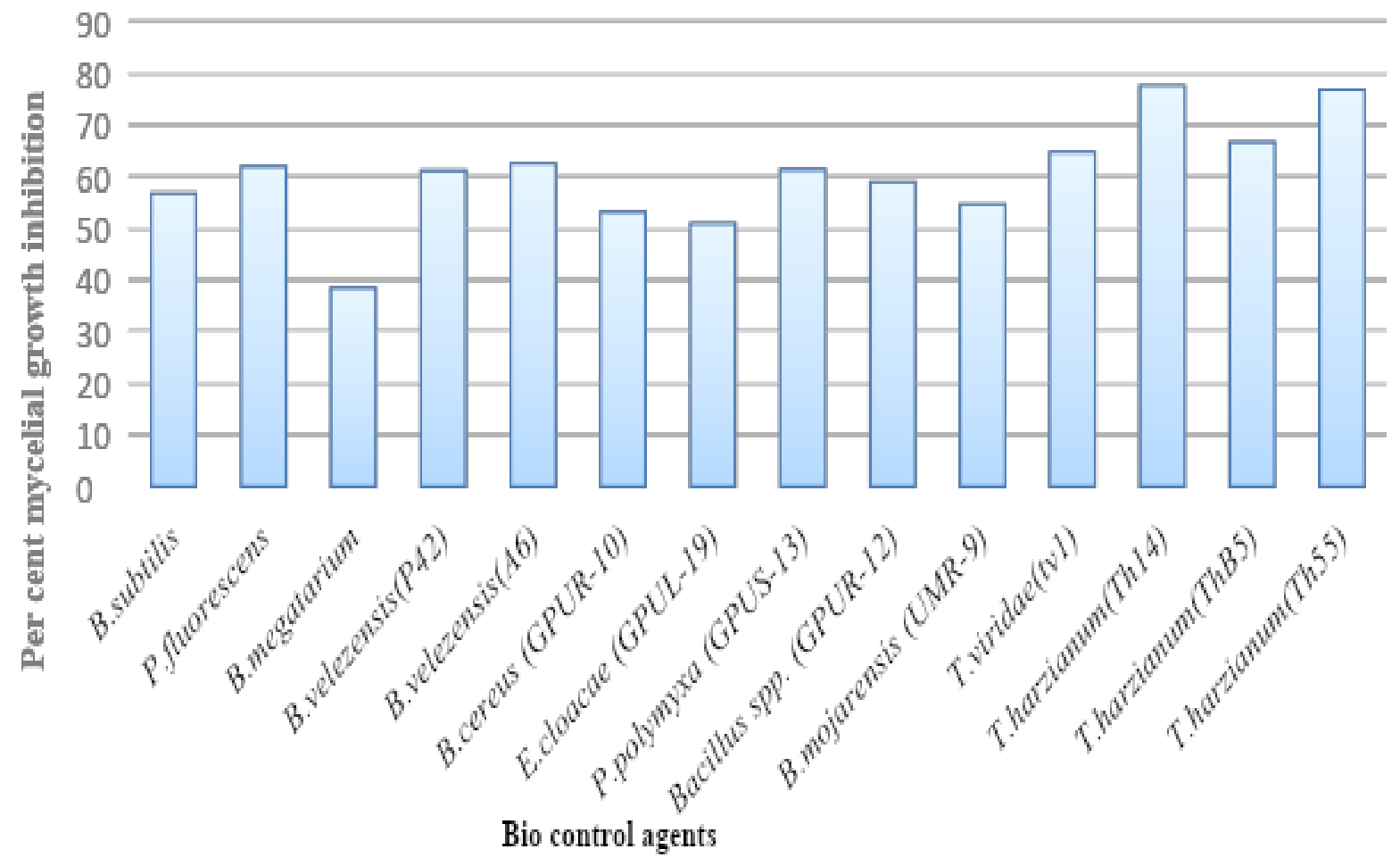

Fig.2 Effect of bio agents on the mycelial growth inhibition of P.setariae (Volatile metabolites) 


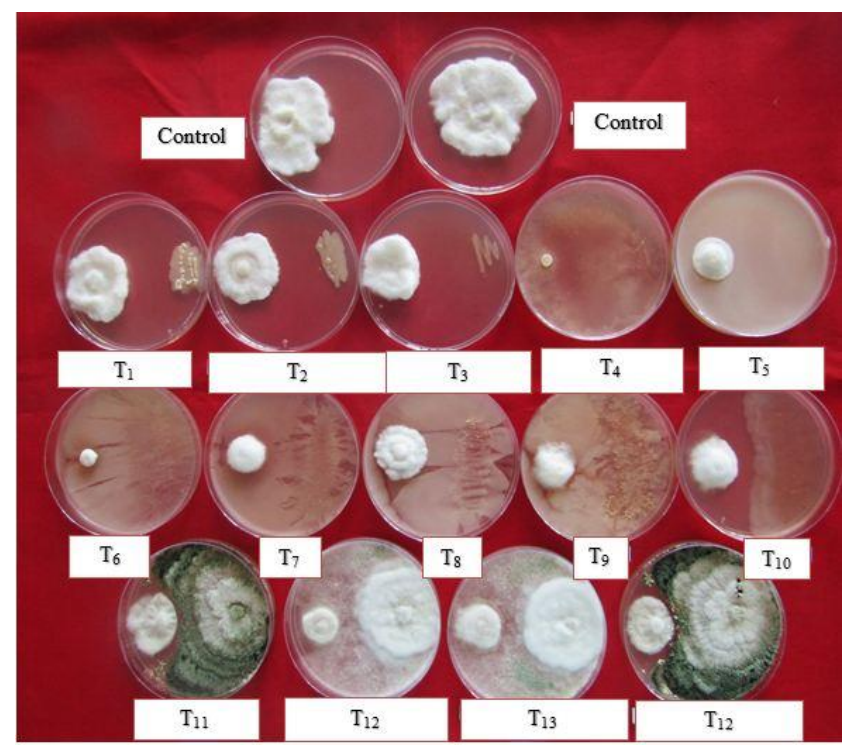

Plate.1 Efficacy of bio agents on inhibition of mycelial growth of P.setariae (Dual culture technique)

$\mathrm{T}_{1}$ - Bacillus subtilis.

$\mathrm{T}_{4}$ - B. velezensis $\left(\mathrm{P}_{42}\right)$

$\mathrm{T}_{7}$ - B. cereus (GPUR-10)

$\mathrm{T}_{10}-$ B. mojarensis (UMR-9)

$\mathrm{T}_{13}-$ T. harzianum $(T h B 5)$

Note: Figures in the parenthesis are arc sine transformed values
$\mathrm{T}_{2}$-Pseudomonas fluorescens
$\mathrm{T}_{5}$ - B. velezensis (A6)
$\mathrm{T}_{3}-$ B. megatarium
$\mathrm{T}_{8}$ - Pennibacillus polymyxa (GPUS-13) $\quad \mathrm{T}_{9^{-}}$Bacillus spp. (GPUR-12)
$\mathrm{T}_{11}$ - Trichoderma virida (Tv1)
$\mathrm{T}_{6}$ - Enterobacter cloacae (GPUL-19
$\mathrm{T}_{14}-$ T. harzianum $(T h 55)$

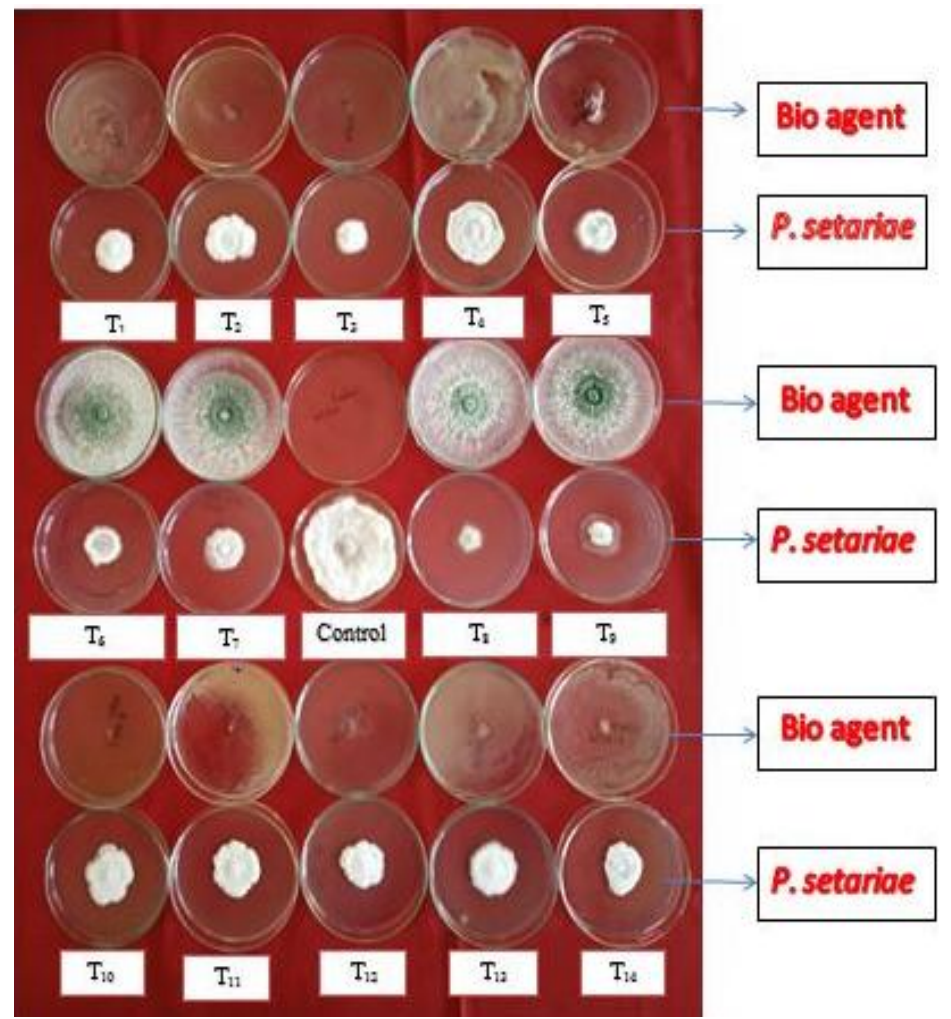

Plate.2 Efficacy of bio agents on inhibition of mycelial growth of P.setariae (Volatile method)

T1- Pseudomonas fluorescens.

T4- B. megatarium

T7- Trichoderma viridae (Tv1)

T10- B. cereus (GPUR-10)

T13- Bacillus spp. (GPUR-12)
$\mathrm{T} 2-$ Bacillus velezensis $(\mathrm{P} 42)$

T5- B. subtilis

T3- Bacillus velezensis (A6)

T6- T. harzianum (ThB5)

T8- T. harzianum (Th14)

T9- T. harzianum (Th55)

T11- B. mojarensis (UMR-9) T12- Enterobacter cloacae (GPUL-19)

T14- Pennibacillus polymyxa (GPUS-13) 
Among fourteen biocontrol agents evaluated $\mathrm{P}_{42}$ strain of Bacillus velezensis showed cent per cent inhibition of mycelial growth followed by bacterial endophyte Enterobacter cloacae and least inhibition of mycelial growth observed in Bacillus megatorium.

Among fungal antagonists Th14 strain of Trichoderma harzianum showed highest mycelial growth inhibition followed by $T h \mathrm{~B} 5$ strain of $T$. harzianum and least mycelial growth inhibition was noticed in Th55 strain of $T$. harzianum. Identified potential bio control agents will be used in designing Integrated Disease Management strategies for management of blast there by production and productivity of the crop will be enhanced.

\section{References}

Ali, H. and Nadarajah, K., 2014, Evaluating the efficacy of Trichoderma spp and Bacillus substilis as biocontrol agents against Magnaporthe grisea in rice. Aus. J. Crop. Sci., 8 (9): 1324-1335.

Arumugam, K., Ramalingam, P. and Appu, M., 2013, Isolation of Trichoderma viride and Pseudomonas fluorescens organism from soil and their treatment against rice pathogens. J. Microbiol. Biotech. Res., 3 (6):77-81.

Baker, R. D., 2003, Millet production (Guide A-414), New Mexico State University.

Choi, Y., Osada, K., Ito, Y., Nagasawa, T., Choi, M. and Nishizawa, N., 2005, Effects of dietary protein of Korean foxtail millet on plasma adinopectin, HDL-cholesterol and insulin levels in genetically type 2 diabetic mice. Biosci. Biotechnol. Biochem., 69:31-37.

Fuji, K., Fujita, E., Takaishi, Y., Fujita, T., Arita, I., Komatsu, M. and Hiratsuka, N., 1978, New antibiotics, trichopolyns $A$ and B: Isolation and biological activity. Experientia., 34: 237-239.

Gaikwad, A. P. and D' Souza, T. F., 1987, A comparative study on Pyricularia spp. J. Maharashtra Agril. Uni., 12: 134135.

Gouramanis, G.D., 1997, Biological and chemical control of rice blast disease in North Greece. Cahiers Options Mediterraneennes., 15: 61-68.

Hajano, J., Lodhi, A. M., Mumtaz, A. P., Khanzada, M. A. and Shah, S. G., 2012, In vitro evaluation of fungicides, plant extracts and biocontrol agents against rice blast pathogen Magnaporthe oryzae Couch. Pak. J. Bot., 44 (5): 1775-1778.

Kalaivani, N., Hamdia, Z. A. and Nurfarahana, S. O., 2014, The isolation and characterization of an endochitinase gene from a Malaysian isolate of Trichoderma sp. Aust. J. Crop Sci., 8 (5): 711-721.

Karthikeyan, V. and Gnanamanickam, S. S., 2008, Biological control of Setaria blast (M. Grisea) with bacterial strains, Crop Protection, 27 (2): 263-267.

Marathee, J.P., 1993, Structure and characteristics of the world millet economy. pp. 159-178. In: K.W. Riley, S.C. Gupta, A. Seetharam, and J.N. Mushonga (Ed.), Advances in small millets. Oxford and IBH Publ.Co. Pvt. Ltd., 66 Janpath, New Delhi.

Rai, M., 2002, Nutritive cereals. In: Survey of Indian Agriculture. The Hindu, Chennai, Tamil Nadu, India. pp 59-62.

Sema, A. and Sarita, S., 2002, Suitability of millet-based food products for diabetics. J. Food Sci. Technol., 39:423-426.

Somashekhar Konda., 2015, Investigations on leaf blast of foxtail millet $\{s$ etaria italica (1.) Beauv.\}. M. Sc. (Agri) Thesis. University of Agricultural Sciences, Bengaluru.

Vavilov, N. I., 1926, Studies on the origin of cultivated plants. Appl. Bot. Plant Breed., 26: 1-248.

Vinale, F., Sivasithamparam, K., Ghisalberti, E., Marra, R., Woo, S. and Lorito, M., 
2008, Trichoderma- plant - pathogen interactions. Soil Biol. Biochem., 40(1): $1-10$.

Vincent, J. M., 1947, Distribution of fungal hyphae in the presence of certain inhibitors. Nature., 159: 850.

Watanabe, N., 1985, Antagonism by various kinds of Trichoderma fungi to airborne plant pathogens. Bull. Faculty Agric., Meiji Univ., 68: 1-9.

Wright, W. G. and Finch, R. C., 1962, Firm seeds in the foxtail millets. Proc. Assoc. off. Seed. Ann. North. America., 52: 109-111.

\section{How to cite this article:}

Mallikarjuna. B., M. S. Nagaraj and Palanna. K. B. 2020. Invitro Evaluation of Bio Control Agents Against Blast of Foxtail Millet Caused by Pyricularia setariae. Int.J.Curr.Microbiol.App.Sci. 9(03): 3019-3027. doi: https://doi.org/10.20546/ijcmas.2020.903.346 